University of Nebraska - Lincoln

DigitalCommons@University of Nebraska - Lincoln

Genetic and Environmental Influences on Leaf Phenology and Cold Hardiness of Native and Introduced Riparian Trees

Jonathan M. Friedman

U.S. Geological Survey, friedmanj@usgs.gov

James E. Roelle

U.S. Geological Survey

Brian S. Cade

U.S. Geological Survey

Follow this and additional works at: https://digitalcommons.unl.edu/usgsstaffpub

Friedman, Jonathan M.; Roelle, James E.; and Cade, Brian S., "Genetic and Environmental Influences on Leaf Phenology and Cold Hardiness of Native and Introduced Riparian Trees" (2011). USGS Staff -Published Research. 732.

https://digitalcommons.unl.edu/usgsstaffpub/732

This Article is brought to you for free and open access by the US Geological Survey at DigitalCommons@University of Nebraska - Lincoln. It has been accepted for inclusion in USGS Staff -- Published Research by an authorized administrator of DigitalCommons@University of Nebraska - Lincoln. 


\title{
Genetic and environmental influences on leaf phenology and cold hardiness of native and introduced riparian trees
}

\author{
Jonathan M. Friedman • James E. Roelle • \\ Brian S. Cade
}

This article is a U.S. government work, and is not subject to copyright in the United States.

Received: 16 November 2010 /Revised: 2 February 2011 /Accepted: 12 February 2011 /Published online: 17 September 2011

(C) US Government 2011

\begin{abstract}
To explore the roles of plasticity and genetic variation in the response to spatial and temporal climate variation, we established a common garden consisting of paired collections of native and introduced riparian trees sampled along a latitudinal gradient. The garden in Fort Collins, Colorado (latitude $40.6^{\circ} \mathrm{N}$ ), included 681 native plains cottonwood (Populus deltoides subsp. monilifera) and introduced saltcedar (Tamarix ramosissima, T. chinensis and hybrids) collected from 15 sites at $29.2-47.6^{\circ} \mathrm{N}$ in the central United States. In the common garden both species showed latitudinal variation in fall, but not spring, leaf phenology, suggesting that the latitudinal gradient in fall phenology observed in the field results at least in part from inherited variation in the critical photoperiod, while the latitudinal gradient in spring phenology observed in the field is largely a plastic response to the temperature gradient. Populations from higher latitudes exhibited earlier bud set and leaf senescence. Cold hardiness varied latitudinally in both fall and spring for both species. For cottonwood, cold hardiness began earlier and ended later in northern than in southern populations. For saltcedar northern populations were hardier throughout the cold season than southern populations. Although cottonwood was hardier than saltcedar in midwinter, the reverse was true in late fall and early spring. The latitudinal variation in fall phenology and cold hardiness of saltcedar appears to have developed as a result of multiple introductions of
\end{abstract}

Electronic supplementary material The online version of this article (doi:10.1007/s00484-011-0494-6) contains supplementary material, which is available to authorized users.

J. M. Friedman $(\bowtie) \cdot$ J. E. Roelle $\cdot$ B. S. Cade

US Geological Survey, Fort Collins Science Center,

2150 Centre Avenue, Building C,

Fort Collins, CO 80526, USA

e-mail: friedmanj@usgs.gov genetically distinct populations, hybridization and natural selection in the 150 years since introduction.

Keywords Cold hardiness · Latitude · Phenology · Rapid evolution $\cdot$ Populus deltoides . Tamarix

\section{Introduction}

For perennial plants in temperate climates, the seasonal timing of the onset and cessation of growth reflects an evolutionary compromise between avoiding frost damage and maximizing growth (Ying and Bagley 1976; Rehfeldt et al. 1999; Howe et al. 2003). This compromise is typically studied in terms of leaf phenology, which is easily observed, without accompanying measurements of seasonal variation in cold hardiness, which are relatively laborious. Measurements of cold hardiness are ecologically important, however, because they directly relate temperature to survival. Cold hardiness varies over time (Tsarouhas et al. 2001), within individual plants (Sakai and Larcher 1987), within populations (Chen et al. 2002), between populations (Repo et al. 2000) and between species (Sakai and Weiser 1973; George et al. 1974), and this variation is not always correlated with variation in leaf phenology (Cannell and Sheppard 1982). Simultaneous measurements of seasonal variation in leaf development and cold hardiness quantify the compromise between maximizing growth and survival and allowing exploration of the extent to which these contemporaneous processes are physiologically coupled (Cannell and Sheppard 1982; Repo et al. 2000).

Because of the latitudinal gradient in temperature, wideranging species often display latitudinal gradients in phenology. Increasing latitude is typically associated with later leaf flush and flowering and earlier growth cessation, 
leaf senescence and onset of cold hardiness (Sakai 1970; Zhang et al. 2004; Borchert et al. 2005). Latitudinal gradients in phenology reflect both genetic variation and a plastic response to the climatic gradient, and commongarden studies can be used to determine the relative importance of these factors (Turesson 1930; Colautti et al. 2009). If phenological variation persists when plants from different latitudes are grown together, then the variation observed in the wild has a genetic component.

The environmental cues controlling leaf development in temperate-zone trees suggest that latitudinal phenological gradients should have a weaker genetic component in the spring than in the fall. Leaf flush in most temperate trees is controlled largely by temperature variation (Pauley and Perry 1954; McMillan 1957; Perry 1971). More specifically, leaf and flower buds open after experiencing critical amounts of chilling and then warming (Arora et al. 2003; but see Linkosalo and Lechowicz 2006). These cues allow a plastic response to climatic variation. For example, in a warm year or location, the threshold of warming will be passed earlier and leaf flush and flowering will occur earlier. Therefore, although genetic variation in spring leaf phenology is common (Farmer 1993), variation in climate over time or latitude does not automatically require evolution of corresponding genetic variation in spring leaf phenology.

In contrast, fall phenology is strongly influenced by light. Growth cessation is triggered in part by reduction of day length below a critical photoperiod (Pauley and Perry 1954; Wareing 1956). Between the summer solstice and the fall equinox, a given day length occurs on a later calendar date at higher latitudes. If all individuals of a species had the same critical photoperiod, growth cessation would be later at higher latitudes, the opposite of the trend observed. In order for growth cessation to be earlier at higher latitudes a strong inherited latitudinal gradient in the critical photoperiod is required (Pauley and Perry 1954; ViheräAarnio et al. 2005). Although plasticity in fall leaf phenology has been reported in response to variation in temperature, and availability of water and nutrients (Arora et al. 2003; Vitasse et al. 2010) the photoperiodic cue is not plastic. A plant population moved to a new latitude or exposed to a shift in climate must evolve a corresponding shift in the critical photoperiod.

Plastic response to change in climate occurs within the life span of an individual. Genetic changes in populations can take many generations. Can such genetic changes occur rapidly enough to respond to human-induced climate change? One way to explore the potential rate of response of organisms to climate change is to study the response of recently introduced species to a novel climate. If physiological control of phenology cannot evolve at the century time scale, then (1) native species must depend upon plasticity and migration to respond to human-induced climate alteration (Saxe et al. 2001; Jump and Peñuelas 2005), and (2) recently introduced species are limited to the same responses to deal with spatial climate variation in the introduced range. On the other hand, if these controls can evolve at the century time scale then (1) evolution of phenology can be part of the response of plants to climate change (Franks et al. 2007), and (2) introduced species may rapidly evolve latitudinal genetic variation in phenology similar to that displayed by native species. This possibility is supported by discovery of clinal variation in several introduced species (Weber and Schmid 1998; Colautti et al. 2009). To attribute clinal variation in an introduced species to natural selection, it is necessary to disprove the null hypothesis that this variation was produced by multiple introductions of genetically distinct populations without subsequent natural selection (Maron et al. 2004).

We examined phenology and cold hardiness in a common garden consisting of paired collections of a native and an introduced species. The selected species were cottonwood and saltcedar, riparian pioneer trees that compete for dominance along rivers throughout most of the western United States (Friedman et al. 2005). The eastern cottonwood (Populus deltoides Bartram ex Marsh.) is a large, fast-growing riparian tree of North America (USDA 2009) displaying strong latitudinal variation in leaf phenology and cold hardiness (Kaszkurewicz and Fogg 1967; Ying and Bagley 1976). P. deltoides is known to be cold hardy in winter; dormant buds and stems can survive chilling to $-80^{\circ} \mathrm{C}$ (Sakai and Weiser 1973). In summer, however, $P$. deltoides can be killed by temperatures of -3 to $-5^{\circ} \mathrm{C}$ (Tsarouhas et al. 2001). Inherited variation in cold hardiness among individual plants is greater in the spring and fall than in the summer and winter (Tsarouhas et al. 2001). We limited our study to plains cottonwood (Populus deltoides ssp. monilifera (Aiton) Eckenwalder), the dominant riparian tree of the western Great Plains, ranging from northern Texas to southern Manitoba, Saskatchewan, and Alberta at latitude $30-55^{\circ} \mathrm{N}$ and longitude $96-114^{\circ} \mathrm{W}$ (Van Haverbeke 1990; Friedman et al. 2005; USDA 2009). The large latitudinal range, the absence of barriers to gene flow (Friedman et al. 2008), and the simple climatic gradient, uncomplicated by mountains or coastal influences, make plains cottonwood ideal for the study of latitudinal variation in leaf phenology and cold hardiness.

Riparian shrubs of the genus Tamarix were introduced to North America in the mid-1800s as ornamental plants and for erosion control (Robinson 1965). Although there are now several Tamarix species in the United States, $T$. chinensis Lour. and T. ramosissima Ledeb. are by far the most abundant (Gaskin and Kazmer 2009). T. chinensis is native to China, Korea, and Japan at latitude $23-42^{\circ} \mathrm{N}$ and longitude $79-110^{\circ} \mathrm{E}$, whereas $T$. ramosissima occurs more 
widely across temperate Asia at latitude $30-53^{\circ} \mathrm{N}$ and longitude $42-127^{\circ} \mathrm{E}$ (Baum 1978). Although these two species are morphologically and genetically distinct in Asia (Baum 1978), the North American population is dominated by their hybrids (Gaskin and Kazmer 2009). Analysis of microsatellites and amplified fragment length polymorphisms along the latitudinal gradient in North America shows that genetic variation within populations is large relative to that between populations, and reveals a gradual genetic gradient with individuals more like $T$. chinensis in the south and individuals more like T. ramosissima in the north (Friedman et al. 2008; Gaskin and Kazmer 2009). We refer to the complex of T. ramosissima, T. chinensis, and their hybrids as saltcedar.

Saltcedar is now the second most abundant riparian woody plant in the interior western United States (Friedman et al. 2005). Because replacement of native cottonwoodwillow (Populus-Salix) communities by saltcedar can be associated with degradation of habitat for vertebrates and increased water loss from evapotranspiration, there is intense interest in controlling its spread (Shafroth et al. 2005). In the United States north of about $39^{\circ} \mathrm{N}$ latitude saltcedar is relatively scarce (Friedman et al. 2005), suggesting that cold sensitivity may limit northward expansion. A comparison of latitudinal gradients in cold hardiness and phenology in cottonwood and saltcedar is valuable for two reasons. First, it makes it possible to explore whether differences in cold hardiness could explain the apparent inferior competitive ability of saltcedar in the north. This information would help to assess the potential for spread of this major invasive species both in the present climate and in response to climate warming. Second, comparing latitudinal variation in the native and introduced species explores whether patterns of clinal variation typical of native species can rapidly evolve in introduced species.

We planted a common garden of paired samples of native cottonwood and introduced saltcedar collected along a latitudinal gradient in the central United States. The feasibility of this approach was demonstrated in a pilot study using limited observations of potted plants grown in a shade house for one winter with no contemporaneous observations of leaf phenology (Friedman et al. 2008). The earlier study suggested the existence of latitudinal genetic variation in cold hardiness for both species. In the present study, we sought to verify the existence of this genetic variation and to quantify it in relation to variation in leaf phenology by making intensive observations over three winters of trees planted outdoors.

\section{Hypotheses}

First, the timing of terminal bud formation and leaf senescence is strongly correlated with the onset of cold hardiness in the fall, and the timing of leaf flush is strongly correlated with the relaxation of cold hardiness in the spring. Second, there is stronger inherited latitudinal variation in cold hardiness and leaf phenology in fall than in spring. Third, there is inherited latitudinal variation in leaf phenology and cold hardiness in the native cottonwood, but not in the introduced saltcedar. Fourth, cottonwood has greater cold hardiness than saltcedar.

\section{Materials and methods}

\section{Common garden}

In February and March of 2005, we collected plains cottonwood and saltcedar as cuttings from 15 sites distributed along a latitudinal gradient from 29.2 to $47.6^{\circ} \mathrm{N}$ in the central United States (Online Resource 1). Sample collection and propagation are described by Friedman et al. (2008). On August 16, 2005 we planted rooted cuttings in a common garden at the Colorado State Nursery in Fort Collins at latitude $40.58^{\circ} \mathrm{N}$ and longitude $105.14^{\circ} \mathrm{W}$. The garden contained 313 cottonwoods and 368 saltcedars planted in a clay loam soil in a random design without blocks, with a spacing of $1.5 \mathrm{~m}$ north-south and $3.0 \mathrm{~m}$ eastwest. Replicates of planted individuals were held over the winter of 2005-2006 and used to replace 90 individuals in the garden that were dead by June 1, 2006. We used a sprinkler system to irrigate the garden when necessary to prevent drought stress until the end of May 2008. We eliminated competition from grasses and herbs using weed barrier, mowing, and occasional application of the herbicide glyphosate (Roundup ${ }^{\circledR}$, Monsanto Corporation, St. Louis, Missouri). We reduced herbivory from deer by fencing and application of deer repellent. Damage from insects and leaf rust was minimal. By summer of 2008 plants were $0.5-3 \mathrm{~m}$ tall, with a multi-branched shrub form. The cottonwoods were not mature enough to flower. All saltcedar flowers were removed to prevent formation of viable, hybrid seeds.

\section{Climate data}

To characterize temperature variation at the common garden we used daily low temperature data for the period 1 April 2005-20 June 2008 from the Christman Field Weather Station located $1 \mathrm{~km}$ from the common garden and operated by the Colorado Climate Center, Colorado State University. To characterize temperature variation at the 15 collection sites we used the DAYMET interpolated daily low temperature series for the period 1980-2003 gridded at 1-km resolution (Thornton et al. 1997; http://www.daymet.org). We used latitude of the sample collection sites as a surrogate for the climatic gradient. Latitude was well correlated with both 
mean annual extreme minimum temperature $\left(r^{2}=0.98\right)$ and mean annual number of frost-free days $\left(r^{2}=0.85\right.$, Online Resource 2).

\section{Leaf and flower phenology}

A single observer made weekly phenological observations of all individuals in the common garden in 2006, 2007, and 2008. We observed the date of leaf flush of both species in the spring of 2007 and 2008, the date of first flowering for saltcedar in 2007 and 2008, the date of cottonwood terminal bud formation in the fall of all three years, and the date of leaf senescence of both species in fall 2007. We defined the date of leaf flush as the first date on which individual leaves were visible on a plant. We defined the date of first flowering of saltcedar as the first date on which flower buds had opened enough that the pink or white color of the enclosed petals was visible. We defined cottonwood bud formation date as the first date on which more than $50 \%$ of the stems on a plant had a terminal bud at least partially formed. We defined the leaf senescence date as the first date on which more than $50 \%$ of the leaves on a plant had dropped or turned yellow.

\section{Cold hardiness}

We measured variation in cold hardiness of plant stems through time, within populations, between latitudes and between species. We used three sampling strategies to explore this variation - a temporally intensive sample, a spatially intensive sample, and a highly replicated sample. The temporally intensive sample characterized temporal variation in cold hardiness of northern and southern saltcedar and cottonwood. Every week from 21 August to 6 November 2007, and from 12 February to 3 June 2008, we collected $40 \mathrm{~cm}$ of stem material from each of ten randomly selected individuals from each of four specieslatitude combinations in the common garden: cottonwood and saltcedar from latitudes 34.9 and $47.6^{\circ} \mathrm{N}$. These two latitudes were selected because they were the most northern and southern latitudes with abundant individuals of both species (Online Resource 1). We cut the 40-cm stem length from each individual into seven 5 -cm stem pieces $(2$ species $\times$ 2 latitudes $\times 10$ individuals $\times 7$ pieces $=280$ pieces each sample day) for cold-hardiness testing.

The spatially intensive sample examined cold hardiness of saltcedar and cottonwood from all available latitudes of origin on nine different days from fall 2006 to spring 2007. On each sample day we collected $40 \mathrm{~cm}$ of stem material from each of ten randomly selected individuals from 27 of the 28 specieslatitude combinations in the common garden (Online Resource 1). A new random sample of individuals was selected on each sample day. Cottonwood from latitude 46.5 was excluded because that latitude had insufficient stem material for these cold hardiness tests. We cut the 40-cm stem length from each individual into seven 5 -cm stem pieces $(27$ species-latitude combinations $\times 10$ individuals $\times 7$ pieces $=$ 1,890 pieces each sample day) for cold-hardiness testing.

The highly replicated sample compared variation in cold hardiness of saltcedar and cottonwood in the common garden, within and between latitudes of origin on five different days in 2007 and 2008. On each sample day we collected $400 \mathrm{~cm}$ of stem material from a total of 24-28 individuals from two to eight latitudes. We cut the $400-\mathrm{cm}$ stem length from each individual into seventy $5-\mathrm{cm}$ stem pieces for cold-hardiness testing.

For all three sampling strategies we measured cold hardiness of stems less than 1 year old and between 4 and $9 \mathrm{~mm}$ in diameter. We cut stems into 5 -cm pieces, removed all leaves, placed pieces vertically in random order in wire racks with $1-\mathrm{cm}$ spacing and, no more than 8 hours after collection, placed the wire racks in a programmable temperature chamber (Test Equity Model 115, Thousand Oaks, CA). The temperature in the chamber followed the same sequence for all cold hardiness tests. Beginning at room temperature (about $24^{\circ} \mathrm{C}$ ), it decreased to $-4^{\circ} \mathrm{C}$ in 15 minutes. After holding at $-4^{\circ} \mathrm{C}$ overnight (13-18 hours) the temperature decreased $5^{\circ} \mathrm{C}$ per hour before reaching the coldest possible setting in the chamber $\left(-70^{\circ} \mathrm{C}\right)$. The temperature remained at $-70^{\circ} \mathrm{C}$ overnight $(10-13$ hours). We removed racks from the chamber at six different temperatures, which varied seasonally depending upon the expected killing temperatures of the twigs. After removing racks from the freezer, we placed them in a refrigerator $\left(4^{\circ} \mathrm{C}\right)$. A seventh set of racks, the control, remained in the refrigerator throughout the cold treatment. Two hours after placing the last racks in the refrigerator, we moved all racks to trays of water 1-2 cm deep at room temperature. We changed the water in the trays daily to prevent spread of fungi. After 12-16 days, we determined survival of pieces by visual observation (Calkins and Swanson 1990; Friedman et al. 2008). Live samples had bright green inner bark and were moist throughout. Dead samples had brown-green inner bark and were dry at the top. In comparison to other methods such as electrolyte leakage and chlorophyll fluorescence, visual observation of survival has the important advantage of allowing direct comparisons between seasons and between species (Calkins and Swanson 1990; Friedman et al. 2008). A disadvantage of this method is that a single categorical observation (dead or alive) contains less information than a quantitative observation. We addressed this limitation by using a large sample size.

\section{Statistical analysis}

We calculated the Pearson correlation matrix of all pairwise comparisons between phenological characters using the 
values of each phenological character for each individual in each year. In the correlation matrix, we included killing temperatures of individual plants from the five highly replicated cold hardiness samples.

We used logistic regression to estimate probability of dying as a function of temperature, latitude of origin, and species where the dependent response variable was 1 for twigs that died and 0 for twigs that survived. We defined the killing temperature (LT50) as the temperature at which the probability of dying exceeded 0.50 (Friedman et al. 2008): LT50 $=-\hat{\beta}_{0} / \hat{\beta}_{1}$, where $\hat{\beta}_{0}$ was the estimated intercept and $\widehat{\beta}_{1}$ was the estimated temperature effect in the logistic regression (Venables and Ripley 1999, p. 221).

To estimate LT50s by week for each species and latitude in the temporally intensive sample, we performed logistic regressions with fixed effects for temperature (seven levels), species (two categories), and latitude of origin (two categories), including necessary interactions among temperature, species, and latitude to allow separate logistic survival functions (intercepts and slopes) for each species and latitude combination. We estimated confidence intervals $(95 \%)$ on LT50s by simulating parameter estimates 10,000 times from the multivariate normal sample distribution with parameters specified by the estimated variance/covariance matrix of the model, computing the LT50 at each simulation, and then using the 2.5 and 97.5 percentiles of the distribution of simulated LT50s as our estimates. We used the $\operatorname{sim}()$ function from the arm package (Gelman and Hill 2007) for R ( $R$ Development Core Team 2003) to perform the necessary simulations. Forty-two of the 116 logistic functions had complete or near complete separation of dead and surviving twigs by temperature $(\leq 1$ temperature had both dead and live twigs) that produced unusable variance/covariance matrices for simulations. In order to calculate a conservative estimate of confidence intervals in such cases, we found the highest temperature with average mortality greater than 0.5 and arbitrarily changed one stem fragment at that temperature from dead to alive, and we found the lowest temperature with average mortality less than 0.5 and arbitrarily changed one stem fragment at that temperature from alive to dead. Because this adjustment slightly decreased the slope of the relation between mortality and temperature, it produced slightly inflated estimates of the confidence intervals for the LT50.

To estimate LT50s by latitude, species, and date in the spatially intensive sample, we performed logistic regressions using PROC LOGISTIC in SAS ${ }^{\circledR}$ (SAS Institute, Inc., Cary, NC) as a function of temperature. To determine the strength and significance of the latitude effect for a given species on a given date we performed multiple logistic regressions using PROC LOGISTIC in SAS with temperature and latitude as the independent variables (fixed effects).
To estimate LT50s of individual plants in the highly replicated sample, we performed logistic regressions including all individuals of a given species on a given date using mixed effects models in the lme4 package of $\mathrm{R}(\mathrm{R}$ Development Core Team 2003). In these mixed effects logistic regressions, temperature and latitude entered as continuous fixed effects and individual plant was a random effect on the intercept. We determined the proportions of deviance in the mixed effects logistic regression model attributable to individual plants and to latitude by comparison to reduced parameter models (with just fixed effects of temperature, with fixed effects of temperature and random effects of individuals on intercept, and with fixed effects of temperature and latitude). We estimated confidence intervals on the estimated LT50s for individual plants based on simulations as above for the temporally intensive sample.

\section{Results}

\section{Leaf and flower phenology}

The timing of cottonwood terminal bud formation was strongly negatively correlated with latitude (Online Resource 3 and Table 1). In all three autumns studied (20062008), northern cottonwoods formed their terminal buds and ceased extension growth before southern cottonwoods (Online Resource 3). In the years 2006, 2007, and 2008, cottonwoods from latitude 47.6 formed buds 20 days, 37 days, and 23 days before cottonwoods from latitude 34.9 , and the correlations between bud formation date and latitude were $-0.66,-0.84$ and -0.73 (Table 1).

The timing of leaf senescence for both species (measured only in 2007) was also negatively correlated with latitude, but not as strongly as the timing of cottonwood bud formation (Tables 1 and 2). Consistent with the latitudinal effect on bud formation, leaves of northern individuals of both species became senescent before those of southern individuals (Online Resource 3). The time difference between leaf senescence at latitudes 34.9 and $47.6^{\circ} \mathrm{N}$ was larger in cottonwood (21 days) than in saltcedar (10 days), and the correlation between latitude and leaf senescence date was stronger in cottonwood $(-0.58)$ than in saltcedar $(-0.37)$ (Tables 1 and 2). For latitude $47.6^{\circ} \mathrm{N}$, saltcedar leaves became senescent 1 day before those of cottonwood, but for latitude $34.9^{\circ} \mathrm{N}$ leaves of saltcedar became senescent 12 days before those of cottonwood (Online Resource 3).

The timing of spring leaf flush was not correlated with latitude in cottonwood and weakly and inconsistently correlated with latitude in saltcedar (Tables 1 and 2). However, the date of leaf flush in 2007 was correlated to that of 2008 for both species (Tables 1 and 2), indicating that individuals that were late in 2007 tended to be late in 
Table 1 Correlation matrix relating observations of phenological characters and cold hardiness of plains cottonwood individuals in the common garden, Fort Collins, Colorado. Triplets of values consist of the Pearson correlation coefficient, $r$, above the correlation probability, $p$, and sample size. Significant correlations $(p<0.05)$ are given in bold

\begin{tabular}{|c|c|c|c|c|c|c|c|c|c|c|}
\hline \multirow[t]{3}{*}{ Character } & \multirow{2}{*}{\multicolumn{2}{|c|}{$\frac{\text { Spring phenology }}{\text { Leaf flush }}$}} & \multicolumn{3}{|c|}{ Killing temperature } & \multicolumn{4}{|c|}{ Fall phenology } & \multirow[t]{3}{*}{ Latitude } \\
\hline & & & \multirow{2}{*}{$\begin{array}{l}\text { Spring } \\
\text { 30-Apr-08 }\end{array}$} & \multicolumn{2}{|l|}{ Fall } & \multicolumn{3}{|c|}{ Bud formation } & \multirow{2}{*}{$\begin{array}{l}\text { Leaf senescence } \\
2007\end{array}$} & \\
\hline & 2007 & 2008 & & 18-Sep-07 & 24-Sep-08 & 2006 & 2007 & 2008 & & \\
\hline \multicolumn{11}{|c|}{ Spring phenology } \\
\hline \multicolumn{11}{|l|}{ Leaf flush } \\
\hline \multirow[t]{3}{*}{2007} & 1.00 & 0.46 & -0.55 & 0.002 & 0.16 & -0.07 & -0.10 & -0.08 & 0.01 & 0.09 \\
\hline & & $<.0001$ & 0.006 & 1.00 & 0.40 & 0.26 & 0.10 & 0.15 & 0.80 & 0.13 \\
\hline & 302 & 299 & 24 & 14 & 28 & 237 & 296 & 302 & 302 & 302 \\
\hline \multirow[t]{3}{*}{2008} & & 1.00 & -0.06 & -0.15 & 0.33 & 0.12 & 0.04 & 0.10 & 0.07 & -0.06 \\
\hline & & & 0.79 & 0.62 & 0.09 & 0.08 & 0.44 & 0.10 & 0.22 & 0.31 \\
\hline & & 300 & 24 & 14 & 28 & 235 & 295 & 300 & 300 & 300 \\
\hline \multicolumn{11}{|c|}{ Killing temperature } \\
\hline \multicolumn{11}{|l|}{ Spring } \\
\hline \multirow[t]{3}{*}{ 30-Apr-08 } & & & 1.00 & & 0.10 & 0.09 & 0.38 & 0.32 & 0.11 & -0.51 \\
\hline & & & & & 0.72 & 0.72 & 0.07 & 0.13 & 0.61 & 0.012 \\
\hline & & & 24 & 2 & 16 & 19 & 24 & 24 & 24 & 24 \\
\hline \multicolumn{11}{|l|}{ Fall } \\
\hline \multirow[t]{3}{*}{ 18-Sep-07 } & & & & 1.00 & 0.91 & -0.58 & 0.75 & 0.80 & 0.67 & -0.80 \\
\hline & & & & & $<.0001$ & 0.13 & 0.002 & 0.0006 & 0.009 & 0.0005 \\
\hline & & & & 14 & 14 & 8 & 14 & 14 & 14 & 14 \\
\hline \multirow[t]{3}{*}{ 24-Sep-08 } & & & & & 1.00 & 0.44 & 0.88 & 0.77 & 0.83 & -0.87 \\
\hline & & & & & & 0.05 & $<.0001$ & $<.0001$ & $<.0001$ & $<.0001$ \\
\hline & & & & & 28 & 21 & 28 & 28 & 28 & 28 \\
\hline \multicolumn{11}{|c|}{ Fall phenology } \\
\hline \multicolumn{11}{|c|}{ Bud formation } \\
\hline \multirow[t]{3}{*}{2006} & & & & & & 1.00 & 0.64 & 0.50 & 0.51 & -0.66 \\
\hline & & & & & & & $<.0001$ & $<.0001$ & $<.0001$ & $<.0001$ \\
\hline & & & & & & 238 & 237 & 238 & 238 & 238 \\
\hline \multirow[t]{3}{*}{2007} & & & & & & & 1.00 & 0.73 & 0.55 & -0.84 \\
\hline & & & & & & & & $<.0001$ & $<.0001$ & $<.0001$ \\
\hline & & & & & & & 297 & 297 & 297 & 297 \\
\hline \multirow[t]{3}{*}{2008} & & & & & & & & 1.00 & 0.58 & -0.73 \\
\hline & & & & & & & & & $<.0001$ & $<.0001$ \\
\hline & & & & & & & & 303 & 303 & 303 \\
\hline Leaf senesc & & & & & & & & & & \\
\hline 2007 & & & & & & & & & 1.00 & -0.58 \\
\hline & & & & & & & & & & $<.0001$ \\
\hline & & & & & & & & & 303 & 303 \\
\hline Latitude & & & & & & & & & & 1.00 \\
\hline & & & & & & & & & & 313 \\
\hline
\end{tabular}

2008 as well. Leaf flush occurred earlier in saltcedar than in cottonwood by 22 days in 2007 and 21 days in 2008. Leaf flush of both species occurred about 2 weeks later in 2008 than in 2007 (Online Resource 3). Phenological pattern in the date of first flowering of saltcedar was similar to that in leaf flush of both species. The date of first flowering of saltcedar in 2007 and 2008 was unrelated to latitude (Table 2), but the date of first flowering in 2007 was correlated with that of 2008 (Table 2), indicating that individuals that flowered late in 2007 tended to flower late in 2008 as well. 
Table 2 Correlation matrix relating observations of phenological characters and cold hardiness of saltcedar individuals in the common garden, Fort Collins, Colorado. Triplets of values consist of the
Pearson correlation coefficient, $\mathrm{r}$, above the correlation probability, $p$, and sample size. Significant correlations $(p<0.05)$ are given in bold

\begin{tabular}{|c|c|c|c|c|c|c|c|c|c|}
\hline \multirow[t]{3}{*}{ Character } & \multicolumn{4}{|c|}{ Spring phenology } & \multicolumn{3}{|c|}{ Killing temperature } & \multirow{3}{*}{$\begin{array}{l}\text { Fall phenology } \\
\text { Leaf senescence } \\
2007\end{array}$} & \multirow[t]{3}{*}{ Latitude } \\
\hline & \multicolumn{2}{|c|}{ Leaf flush } & \multicolumn{2}{|c|}{ First flower } & \multicolumn{2}{|l|}{ Spring } & \multirow{2}{*}{$\begin{array}{l}\text { Fall } \\
\text { 18-Sep-07 }\end{array}$} & & \\
\hline & 2007 & 2008 & 2007 & 2008 & 12-Mar-08 & 7-Apr-08 & & & \\
\hline \multicolumn{10}{|c|}{ Spring phenology } \\
\hline \multicolumn{10}{|l|}{ Leaf flush } \\
\hline \multirow[t]{3}{*}{2007} & 1.00 & 0.37 & 0.09 & 0.07 & 0.18 & -0.33 & 0.22 & 0.12 & -0.17 \\
\hline & & $<.0001$ & 0.11 & 0.26 & 0.35 & 0.12 & 0.45 & 0.03 & 0.003 \\
\hline & 327 & 324 & 296 & 296 & 28 & 23 & 14 & 327 & 327 \\
\hline \multirow[t]{3}{*}{2008} & & 1.00 & -0.01 & 0.19 & -0.33 & -0.60 & -0.21 & -0.03 & 0.13 \\
\hline & & & 0.85 & 0.001 & 0.09 & 0.002 & 0.48 & 0.59 & 0.02 \\
\hline & & 333 & 294 & 298 & 28 & 23 & 14 & 333 & 333 \\
\hline \multicolumn{10}{|l|}{ First flower } \\
\hline \multirow[t]{3}{*}{2007} & & & 1.00 & 0.34 & -0.07 & 0.07 & -0.11 & 0.07 & -0.06 \\
\hline & & & & $<.0001$ & 0.72 & 0.75 & 0.74 & 0.20 & 0.31 \\
\hline & & & 298 & 277 & 28 & 20 & 12 & 298 & 298 \\
\hline \multirow[t]{3}{*}{2008} & & & & 1.00 & -0.41 & 0.04 & -0.31 & -0.08 & 0.04 \\
\hline & & & & & 0.04 & 0.89 & 0.35 & 0.17 & 0.55 \\
\hline & & & & 298 & 26 & 18 & 11 & 298 & 298 \\
\hline \multicolumn{10}{|c|}{ Killing temperature } \\
\hline \multicolumn{10}{|l|}{ Spring } \\
\hline \multirow[t]{3}{*}{ 12-Mar-08 } & & & & & 1.00 & & -1 & 0.13 & -0.63 \\
\hline & & & & & & & & 0.50 & 0.0004 \\
\hline & & & & & 28 & 0 & 2 & 28 & 28 \\
\hline \multirow[t]{3}{*}{ 7-Apr-08 } & & & & & & 1.00 & & 0.002 & -0.69 \\
\hline & & & & & & & & 0.99 & 0.0003 \\
\hline & & & & & & 23 & 1 & 23 & 23 \\
\hline \multicolumn{10}{|l|}{ Fall } \\
\hline \multirow[t]{3}{*}{ 18-Sep-07 } & & & & & & & 1.00 & 0.56 & -0.82 \\
\hline & & & & & & & & 0.04 & 0.0004 \\
\hline & & & & & & & 14 & 14 & 14 \\
\hline \multicolumn{10}{|c|}{ Fall phenology } \\
\hline \multicolumn{10}{|c|}{ Leaf senescence } \\
\hline \multirow[t]{3}{*}{2007} & & & & & & & & 1.00 & -0.37 \\
\hline & & & & & & & & & $<.0001$ \\
\hline & & & & & & & & 343 & 343 \\
\hline \multirow[t]{2}{*}{ Latitude } & & & & & & & & & 1.00 \\
\hline & & & & & & & & & 368 \\
\hline
\end{tabular}

The fall phenological characters, leaf senescence and cottonwood bud formation, were correlated with latitude and each other within and between years (Table 1). For example, individuals that formed buds early in 2006 tended also to drop leaves early in 2007. In contrast, spring phenological characters, leaf flush and saltcedar first flowering, were only weakly correlated with latitude and each other (Table 2). There was little correlation between fall phenological characters and spring phenological characters (Tables 1 and 2).

Cold hardiness

Stems of both cottonwood and saltcedar survived colder temperatures in winter than in summer, but this seasonal cycle was stronger in cottonwood than in saltcedar (Figs. 1 and 2); as 


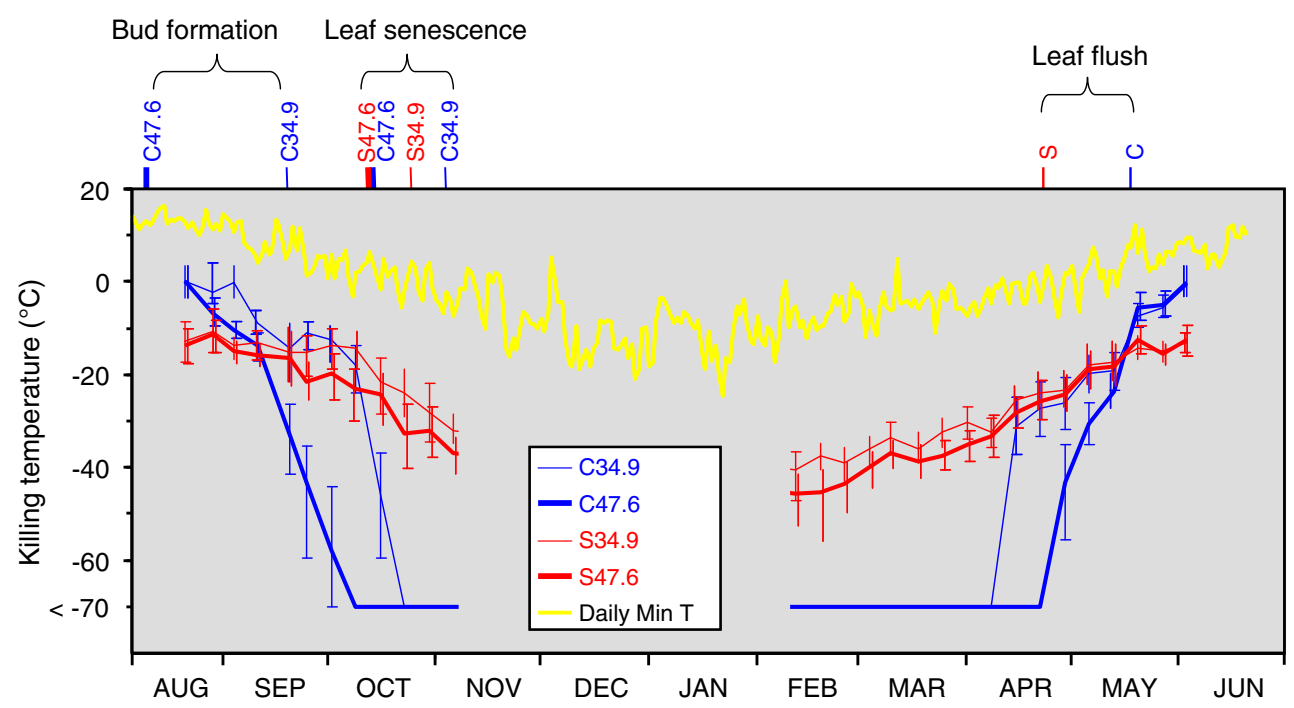

Fig. 1 Temporal variation in killing temperature (LT50) for twigs of northern and southern plains cottonwood and saltcedar grown in Fort Collins, Colorado (latitude $40.6^{\circ} \mathrm{N}$ ) during fall 2007 and spring 2008 (the temporally intensive sample). Northern individuals are from Fort Peck Reservoir, Montana, latitude $47.6^{\circ} \mathrm{N}$ and southern individuals are from Buffalo Lake National Wildlife Refuge, Texas, latitude $34.9^{\circ} \mathrm{N}$. Saltcedar (cottonwood) data are red (blue) labeled S (c). Northern (southern) populations are indicated by thick (thin) lines. Error bars are $95 \%$ confidence intervals and are displayed without horizontal end caps in cases where data were adjusted to avoid complete separation. Error bars are jittered in the $x$ direction to eliminate over-plotting. Mean values for leaf flush, bud formation and leaf senescence are shown above the graph. Daily minimum temperature data are from the Christman Field Weather Station (Colorado Climate Center) about $1 \mathrm{~km}$ from the common garden a result cottonwood was hardier in midwinter, but saltcedar was hardier in the late spring and early fall. On 21 August
2007, saltcedar from latitudes 34.9 and $47.6^{\circ} \mathrm{N}$ had killing temperatures around $-13^{\circ} \mathrm{C}$, while cottonwood from the same
Fig. 2 Latitudinal variation in killing temperature (LT50) for twigs of plains cottonwood during fall 2006 (a) and spring 2007 (b), and saltcedar during fall 2006 (c) and spring 2007 (d) (the spatially intensive sample). Each line represents data collected on a single date. Solid (dotted) lines indicate that the effect of latitude was significant (insignificant) at the 0.05 level in multiple logistic regression. Line and dot thickness are varied arbitrarily for clarity. Plant collection locations are shown in Online Resource 1

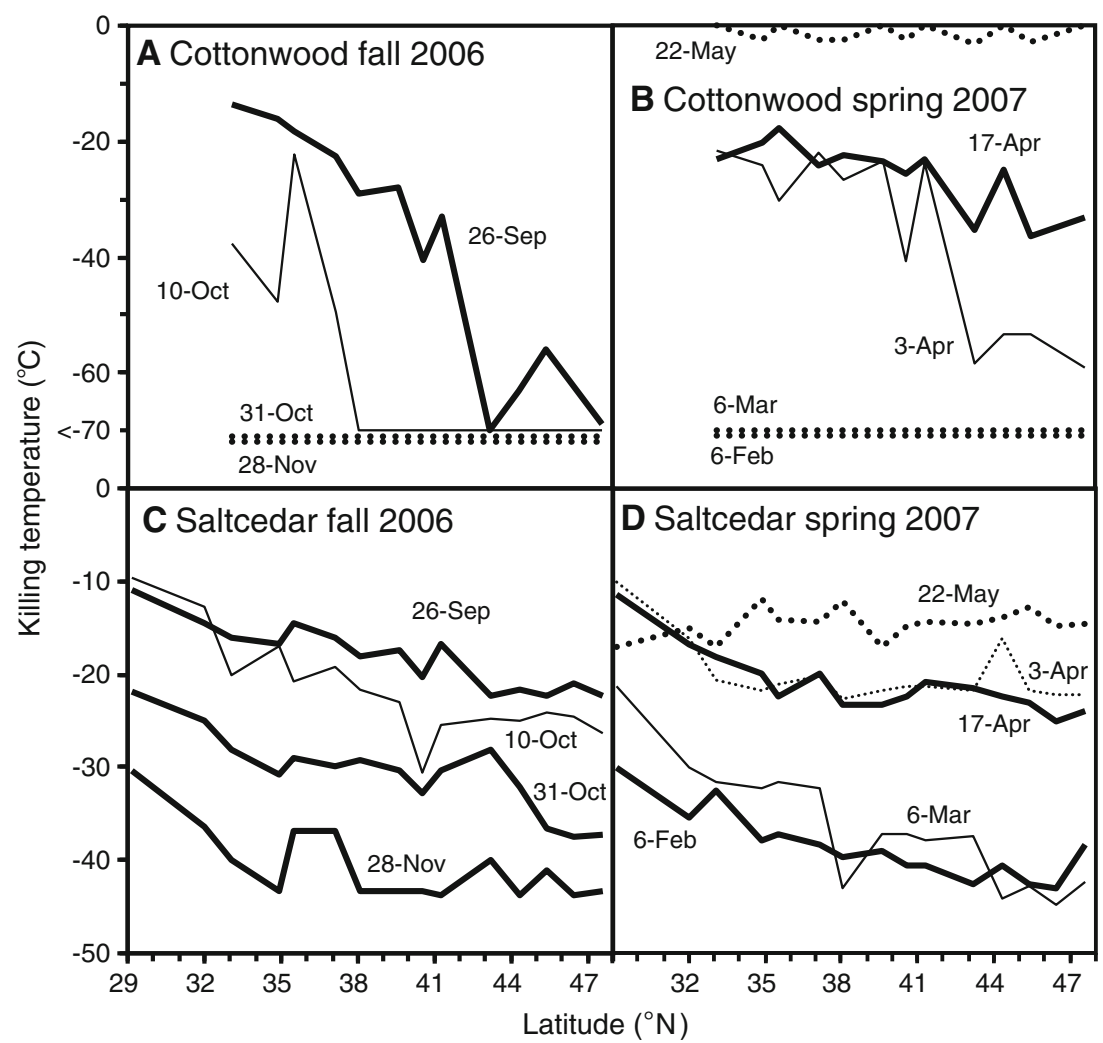


latitudes was killed by temperatures around $0^{\circ} \mathrm{C}$ (Fig. 1). In autumn, killing temperatures for saltcedar gradually decreased, reaching a minimum in mid-winter. Saltcedar from latitudes 34.9 and $47.6^{\circ} \mathrm{N}$ survived temperatures of $-41^{\circ} \mathrm{C}$ and $-46^{\circ} \mathrm{C}$ on 12 February 2008. In contrast, killing temperatures decreased precipitously for cottonwood. By mid-October 2007 cottonwood from both 34.9 and $47.6^{\circ} \mathrm{N}$ latitude survived $-70^{\circ} \mathrm{C}$, the coldest temperature attainable in our temperature chamber. Temperatures of $-70^{\circ} \mathrm{C}$ or warmer did not kill cottonwood again until April 2008 (Fig. 1).

Both cottonwood and saltcedar demonstrated inherited latitudinal variation in cold hardiness in the winters of 2007-2008 (Fig. 3 and Table 3) and 2006-2007 (Fig. 2), confirming conclusions of a pilot study of potted plants carried out in a nearby shade house in the winter of 20052006 (Friedman et al. 2008). In saltcedar, northern populations survived colder temperatures than southern populations throughout the cold season (Figs. 1 and 2). The difference in killing temperature for the extreme latitudes on the gradient $\left(29.2\right.$ and $\left.47.6^{\circ} \mathrm{N}\right)$ reached a maximum of $15-20^{\circ} \mathrm{C}$ in the spring and fall and decreased to about $10^{\circ} \mathrm{C}$ in mid-winter (Fig. 2).

For cottonwood the latitudinal effect was manifested as a difference in the timing of a critical threshold in fall and spring. All latitudes had similar killing temperatures in the summer, underwent a period of rapid cold hardening, and by mid-winter could survive temperatures colder than any that occur in the study region. The coldest daily low temperature in the 24-year record (1980-2003) for the northernmost site $\left(47.6^{\circ} \mathrm{N}\right.$ latitude) was $-41^{\circ} \mathrm{C}$, but all cottonwoods survived $10-13$ hours at $-70^{\circ} \mathrm{C}$ from November through March in the winters of 2006-2007 and 2007-2008 (Figs. 1 and 2). In both winters the northern populations hardened off earlier in the fall and emerged from cold hardiness later in the spring. Temporally intensive sampling in the winter of 2007-2008 demonstrated that the plants from a given latitude passed through the threshold in 2 to 3 weeks and that latitudes 34.9 and $47.6^{\circ} \mathrm{N}$ passed through the threshold 2 to 3 weeks apart (Fig. 1). Spatially intensive sampling in the winter of 2006-2007 located the threshold on three different dates: 26 September 2006, 10 October 2006, and 3 April 2007 (Fig. 2). In contrast to cottonwood, saltcedar did not display a threshold in the onset or termination of cold hardiness. Cold hardiness of saltcedar developed gradually in the fall and subsided gradually in the spring (Figs. 1 and 2). The magnitude of the latitudinal effect for saltcedar also changed gradually over time, reaching a maximum in the fall and spring, but persisting through the winter (Fig. 2).

In both cottonwood and saltcedar there was variation in cold hardiness among individuals from the same latitude that was similar in magnitude to the variation between latitudes (Fig. 3, Table 3). In mixed effects logistic regression of the highly replicated samples, models including the effects of temperature, latitude, and individual within latitude always had much lower deviance than models including temperature alone, and $27-78 \%$ of this reduction in deviance could be attributed to latitude (Table 3). Individuals from the same latitude collected on the same day often differed significantly in killing temperature (Fig. 3). On April 30, 2008, the latitudinal effect for cottonwood was small (Table 3 ) because the time of strongest latitudinal contrast had already passed (Fig. 1).

For cottonwood, bud formation (growth cessation) occurred prior to the beginning of development of cold hardiness, and leaf senescence occurred after plants could

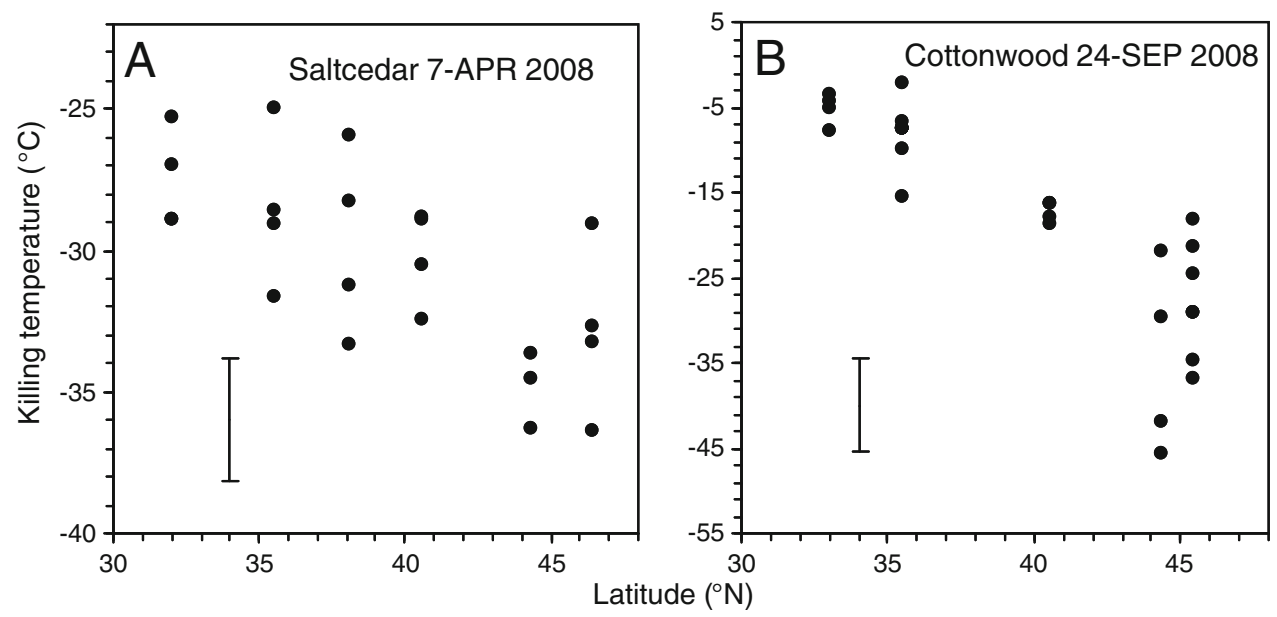

Fig. 3 Variation in killing temperature (LT50) within and between latitudes for twigs of saltcedar (a) on April 7, 2008 and plains cottonwood (b) on September 24, 2008 (the highly replicated sample). Each point is an individual plant. The magnitude of the single plotted error bar is the mean $95 \%$ confidence interval for individuals in the sample: $4.37^{\circ} \mathrm{C}$ (range $3.72-5.17^{\circ} \mathrm{C}$ ) for saltcedar on 7 April 2008 and $11.05^{\circ} \mathrm{C}$ (range $9.34-12.52^{\circ} \mathrm{C}$ ) for cottonwood on 24 September 2008 , calculated using mixed effects logistic regression. Results of these and four other tests are summarized in Table 3 
Table 3 Variation within and between latitudes in mixed effects logistic regression models of cold hardiness of cottonwood and saltcedar (the highly replicated sample). Deviance is given for models based on temperature alone $(\mathrm{T})$, temperature and latitude $(\mathrm{T}+\mathrm{L})$, and temperature, latitude, and individual within latitude $(\mathrm{T}+\mathrm{L}+\mathrm{I})$. The full model $(\mathrm{T}+\mathrm{L}+\mathrm{I})$ always has reduced deviance compared to the model with temperature alone (T), and the latitude contribution is the proportion of that reduction in deviance that can be attributed to latitude: latitude contribution $=[\operatorname{Dev}(\mathrm{T})-\operatorname{Dev}(\mathrm{T}+\mathrm{L})] /[\operatorname{Dev}(\mathrm{T})-\operatorname{Dev}$ $(\mathrm{T}+\mathrm{L}+\mathrm{I})]$, where $\operatorname{Dev}(\mathrm{T}), \operatorname{Dev}(\mathrm{T}+\mathrm{L})$, and $\operatorname{Dev}(\mathrm{T}+\mathrm{L}+\mathrm{I})$ are the deviances of the three models

\begin{tabular}{llllll}
\hline Species & Date & \multicolumn{2}{l}{ Deviance } & & Latitude contribution \\
\cline { 3 - 5 } & & $\mathrm{T}$ & $\mathrm{T}+\mathrm{L}$ & $\mathrm{T}+\mathrm{L}+\mathrm{I}$ \\
\hline Cottonwood & 18-Sep-07 & 588.5 & 419.1 & 307.2 & 0.60 \\
& 30-Apr-08 & 1123.3 & 998.1 & 657.2 & 0.27 \\
Saltcedar & 24-Sep-08 & 1556.5 & 1115.9 & 960.5 & 0.74 \\
& 18-Sep-07 & 480.9 & 472.5 & 470.1 & 0.78 \\
& 12-Mar-08 & 1038.5 & 950.5 & 814 & 0.39 \\
& 7-Apr-08 & 661.3 & 561.1 & 438.8 & 0.45 \\
\end{tabular}

survive temperatures below $-70^{\circ} \mathrm{C}$ (Fig. 1). For saltcedar, bud formation was not observable, but leaf senescence occurred just after the killing temperature had fallen below $-20^{\circ} \mathrm{C}$. In fall there was latitudinal variation in cold hardiness of both species while the leaves were still active (Fig. 1). In contrast, spring leaf flush in both species coincided with the end of latitudinal variation in cold hardiness (Fig. 1). Cold hardiness was strongly correlated with latitude in both the spring and fall (Table 1), but in the one case where the same individuals were tested in both spring and fall (16 cottonwoods tested on both 30 April 2008 and 24 September 2008), spring cold hardiness was not significantly correlated with fall cold hardiness (Table 1).

\section{Discussion}

\section{Species differences}

In mid-winter all plains cottonwoods survived colder temperatures than occur in the range of this species, suggesting that exposure to extreme cold in mid-winter is not an important mortality factor (Sakai and Weiser 1973; Tsarouhas et al. 2001; Morin et al. 2007). In contrast, saltcedar, even when completely hardened off, was killed by temperatures around $-40^{\circ} \mathrm{C}$, which is within the temperature range of the northern Great Plains. The superior cold hardiness of cottonwood over saltcedar was especially prolonged for plants from northern latitudes, where cold stress is likely to be most important. At latitude $47.6^{\circ} \mathrm{N}$ cottonwood was more hardy than saltcedar from mid-September to early May, while at latitude $34.9^{\circ} \mathrm{N}$ cottonwood was more hardy than saltcedar only from midOctober to early April.

The greater winter cold hardiness of cottonwood relative to saltcedar is corroborated by other evidence from the common garden and elsewhere. We observed disproportionate winter mortality and dieback of southern saltcedar, but not southern cottonwood, in our common garden (Online Resource 4) and in a related shade house study (Friedman et al. 2008). Whereas saltcedar stems grow to large size and age in the southern United States, northern stems are smaller and often older below ground than above, indicating that winter die-back is common in the north (Lesica and Miles 2001). Finally, although T. ramosissima occurs in areas of northern China and Mongolia as cold as our coldest collection sites in northern Montana (Baum 1978), the occurrence of saltcedar in the western United States is strongly correlated with mild winter temperatures (Friedman et al. 2005). We conclude that winter cold is a significant factor influencing distribution of saltcedar in the United States. Increases in winter low temperatures could promote northward spread of saltcedar in the future.

Although cottonwood is extremely cold hardy in midwinter (Sakai and Weiser 1973) it is less hardy than saltcedar in the early spring and late fall. In late August and mid-May cottonwood stems were almost all killed by 13-18 hours at $-4^{\circ} \mathrm{C}$ and unharmed by exposure to $4^{\circ} \mathrm{C}$, which is corroborated by experimental observations of cold damage on Populus spp. at temperatures between $-3^{\circ} \mathrm{C}$ and $-5^{\circ} \mathrm{C}$ during the growing season (Tsarouhas et al. 2001). Although we observed no fall or spring damage to cottonwood in our common garden, Ying and Bagley (1976) observed over-winter damage to southern cottonwoods transplanted northwards and attributed this damage to fall frost injury resulting from late growth cessation. Leaf flush in cottonwood coincided with a sharp decrease in cold hardiness. This sensitivity to cold in spring may explain the late leaf flush of cottonwood relative to saltcedar. Plains cottonwood leaf buds from several sites across Nebraska opened after those of three other dominant trees in the western Great Plains, Ulmus americana, Fraxinus pennsylvanica, and 
Acer negundo, and at the same time as those of Quercus macrocarpa (McMillan 1957). Therefore, although cottonwood is extremely hardy in mid-winter, sensitivity to cold after leaf flush limits the growing season for this species.

The onset of cold hardiness in cottonwood was a threshold phenomenon, and the strongest latitudinal differences in cold hardiness were related to the timing of the threshold. Latitudinal differences in cottonwood cold hardiness were nonexistent in mid-summer and ecologically irrelevant in mid-winter. In contrast to cottonwood, saltcedar did not show a threshold in the onset or completion of cold hardiness. Cold hardiness in saltcedar developed and ended gradually, along with the clinal variation. The season of greatest cold hardiness in saltcedar was mid-winter. Although northern saltcedar was hardier than southern saltcedar from fall through spring, the latitudinal effect was stronger in spring and fall than in mid-winter. These results suggest that latitudinal variation in cold hardiness of saltcedar reflects both a greater capacity for cold hardiness in northern saltcedar and a difference in the seasonal timing of the onset of and recovery from cold hardiness.

\section{Latitudinal variation}

As predicted, we found strong inherited variation in fall, but not spring, leaf phenology of cottonwood as a function of latitude of origin. In the field, between latitudes 34.9 and $47.6^{\circ} \mathrm{N}$, the date of leaf flush of Populus deltoides is delayed by about 44 days and the date of growth cessation is advanced by about 32 days (Kaszkurewicz and Fogg 1967). In our common garden, comparing cottonwood populations from latitudes 34.9 and $47.6^{\circ} \mathrm{N}$, leaf flush was unaffected by latitude and the date of growth cessation was advanced by an average of 27 days. These results support the hypothesis that the latitudinal variation in fall leaf phenology observed in the field has a strong genetic component related in part to variation in the critical photoperiod for growth cessation, while the latitudinal variation observed in the field in spring phenology is largely a plastic response to the temperature gradient. Our inference about the relative roles of plasticity and genetic variation is limited by the fact that this study included only a single common garden. One component of plasticity is spatial variation in the strength of the observed genetic effect (Sultan 2000). Our results are consistent, however, with those of other common-garden studies of Populus in North America and Europe (Ying and Bagley 1976; Brissette and Barnes 1984; Farmer 1993; Luquez et al. 2008) and of other temperate forest trees (Nienstaedt 1974), showing greater latitudinal genetic variation in fall than in spring phenology. Furthermore, the lack of correlation between fall and spring phenological characters (Table 1) suggests that these characters are controlled by different physiological processes (Tsarouhas et al. 2001; Howe et al. 2003; Luquez et al. 2008), which was expected given the importance of photoperiod as a cue for fall but not spring leaf phenology.

This argument is consistent with variation in success of phenological models in predicting spring and fall phenology of widely distributed tree species. Spring phenological data for Fraxinus americana, Ulmus americana, and Quercus velutina collected from a single location over a long period were sufficient to calibrate thermal models that successfully predicted spring phenology in remote parts of the ranges of these species (Chuine et al. 2000). Therefore, genetic variation in the temperature sensitivity of spring phenology within these species is relatively small (Vitasse et al. 2009). In contrast, fall phenological data from a single location could not be used to predict fall phenology elsewhere in the range of the same species (Schaber and Badeck 2003). This result reflects the importance of spatial genetic variation in fall phenology, as observed in the present study, as well as complex influences on fall phenology of other factors such as temperature, moisture, nutrient availability, and developmental status (Dunlap and Stettler 1996; Arora et al. 2003). Finally, the plasticity of the temperature cues dominating spring leaf phenology is demonstrated by the spatial and temporal variation in this character exhibited by clones of trees planted across Europe in the International Phenological Gardens. Warming temperatures over the last several decades have caused advancement in the spring phenology of these trees, while changes in fall leaf phenology are smaller and less consistent (Chmielewski and Rötzer 2001; Estrella and Menzel 2006).

Whereas leaf phenology in our common garden varied with latitude of origin in fall but not spring, cold hardiness of cottonwood and saltcedar twigs varied with latitude of origin in both fall and spring. Growth cessation and leaf senescence were tightly coupled to cold hardiness in fall, especially for cottonwood. For a given latitude the onset of cottonwood cold hardiness occurred after growth cessation and before leaf senescence, and there was strong correlation among growth cessation, leaf senescence, and fall cold hardiness within and between years. Similar correlations among latitude, the timing of growth cessation, and the onset of cold hardiness have been reported in conifers (Repo et al. 2000).

In spring, southern cottonwoods and saltcedars emerged from cold hardiness before northern individuals in 2007 and 2008 even though there was no strong or consistent latitudinal trend in leaf flush or saltcedar flowering. These results suggest that emergence from cold hardiness in spring is not tightly coupled to leaf phenology. Similar temporal variation in spring cold hardiness and phenology 
as a function of latitude of origin has been observed in Quercus rubra (Flint 1972) and Picea sitchensis (Cannell and Sheppard 1982). The earlier emergence from cold hardiness of stems of southern accessions may reflect greater activity of processes that can continue during winter in the absence of leaves, such as root growth and translocation within stems (Perry 1971). These processes may occur for extended periods during mild southern winters.

\section{Rapid evolution of phenology}

In spite of its recent introduction to North America, saltcedar showed latitudinal variation in the timing of leaf senescence and cold hardiness from fall through spring. Furthermore, growth chamber experiments comparing northern and southern saltcedar have demonstrated inherited temperature-dependent differences in root-shoot ratio (Sexton et al. 2002). This latitudinal genetic variation appears to have resulted from (1) multiple introductions of genetically distinct populations, including $T$. chinensis in the south and $T$. ramosissima in the north (Gaskin and Kazmer 2009), (2) hybridization that produced a population containing extensive genetic variation for leaf phenology and cold hardiness (Hurka et al. 2003; Friedman et al. 2008), and (3) natural selection. The hypothesis that the observed latitudinal gradient in North America resulted, at least in part, from natural selection after introduction is supported by the fact that North American Tamarix are genetically distinct from Eurasian Tamarix (Gaskin and Kazmer 2009). In addition, in both cottonwood and saltcedar there was strong variation in cold hardiness and leaf phenology within and between the populations collected from different latitudes. In contrast, neutral microsatellite markers from the same plants showed much stronger variation within than between populations (Hall et al. 2007; Friedman et al. 2008).

Global increases in temperature could promote earlier leaf flush in spring and later growth cessation and leaf senescence in fall (Saxe et al. 2001; Linkosalo and Lechowicz 2006). Our results suggest that cottonwood and saltcedar can accomplish earlier leaf flush through plasticity. To the extent that growth cessation is controlled by photoperiod, however, development of later growth cessation will involve migration and natural selection. The development of a phenological cline in introduced saltcedar is evidence that such change can occur in a shrub population within 150 years.

Acknowledgments Funding was provided by the Global Change Research Program, the Fort Collins Science Center, and the Invasive Species Program of the U.S. Geological Survey. The Common Garden was housed by the Colorado State Forest Service Nursery in Fort Collins. Greenhouse work was carried out at Colorado State
University in Fort Collins. J. Roth managed the common garden and collected much of the data. The authors thank G. Auble, L. Benson, and L. Perry and several anonymous referees for constructive reviews. Any use of trade, product, or firm names is for descriptive purposes only and does not imply endorsement by the U.S. Government.

\section{References}

Arora R, Rowland LJ, Tanino K (2003) Induction and release of bud dormancy in woody perennials: a science comes of age. Hortscience 38:911-921

Baum BR (1978) The genus Tamarix. Israel Academy of Sciences and Humanities, Jerusalem

Borchert R, Robertson K, Schwartz MD, Williams-Linera G (2005) Phenology of temperate trees in tropical climates. Int $\mathrm{J}$ Biometeorol 50:57-65

Brissette JC, Barnes BV (1984) Comparisons of phenology and growth of Michigan and western North American sources of Populus tremuloides. Can J For Res 14:789-793

Calkins JB, Swanson BT (1990) The distinction between living and dead plant tissue - viability tests in cold hardiness research. Cryobiology 27:194-211

Cannell MGR, Sheppard LJ (1982) Seasonal changes in the frost hardiness of provenances of Picea sitchensis in Scotland. Forestry 55:137-153

Chen THH, Howe GT, Bradshaw HD Jr (2002) Molecular genetic analysis of dormancy-related traits in poplars. Weed Sci 50:232240

Chmielewski FM, Rötzer T (2001) Response of tree phenology to climate change across Europe. Agric For Meteorol 108:101-112

Chuine I, Cambon G, Comtois P (2000) Scaling phenology from the local to the regional level: advances from species-specific phenological models. Glob Chang Biol 6:943-952

Colautti RI, Maron JL, Barrett SCH (2009) Common garden comparisons of native and introduced plant populations: latitudinal clines can obscure evolutionary inferences. Evol Appl 2:187199

Dunlap JM, Stettler RF (1996) Genetic variation and productivity of Populus trichocarpa and its hybrids. IX. Phenology and Melampsora rust incidence of native black cottonwood clones from four river valleys in Washington. For Ecol Manag 87:233256

Estrella N, Menzel A (2006) Responses of leaf coloring in four deciduous tree species to climate and weather in Germany. Clim Res 32:253-267

Farmer RE (1993) Latitudinal variation in height and phenology of balsam poplar. Silvae Genet 42:148-153

Flint HL (1972) Cold hardiness of twigs of Quercus rubra L. as a function of geographic origin. Ecology 53:1163-1170

Franks SJ, Sim S, Weis AE (2007) Rapid evolution of flowering time by an annual plant in response to a climatic fluctuation. Proc Natl Acad Sci 104:1278-1282

Friedman JM, Auble GT, Shafroth PB, Scott ML, Merigliano MF, Freehling MD, Griffin ER (2005) Dominance of non-native riparian trees in western USA. Biol Invasions 7:747-751

Friedman JM, Roelle JE, Gaskin JF, Pepper AE, Manhart JR (2008) Latitudinal variation in cold hardiness in introduced Tamarix and native Populus. Evol Appl 1:598-607

Gaskin JF, Kazmer DJ (2009) Introgression between invasive saltcedars (Tamarix chinensis and T. ramosissima) in the USA. Biol Invasions 11:1121-1130

Gelman A, Hill J (2007) Data analysis using regression and multilevel/hierarchical models. Cambridge University Press, Cambridge 
George MF, Burke MJ, Pellett HM, Johnson AG (1974) Low temperature exotherms and woody plant distribution. Hortscience 9:519-522

Hall D, Luquez V, Garcia VM, St. Onge KR, Jansson S, Ingvarsson PK (2007) Adaptive population differentiation in phenology across a latitudinal gradient in European aspen (Populus tremula, L.): a comparison of neutral markers, candidate genes and phenotypic traits. Evolution 61:2849-2860

Howe GT, Aitken SN, Neale DB, Jermstad KD, Wheeler NC, Chen THH (2003) From genotype to phenotype: unraveling the complexities of cold adaptation in forest trees. Can J Bot $81: 1247-1266$

Hurka H, Bleeker W, Neuffer B (2003) Evolutionary processes associated with biological invasions in the Brassicaceae. Biol Invasions 5:281-292

Jump AS, Peñuelas J (2005) Running to stand still: adaptation and the response of plants to rapid climate change. Ecol Lett 8:1010-1020

Kaszkurewicz A, Fogg PJ (1967) Growing seasons of cottonwood and sycamore as related to geographic and environmental factors. Ecology 48:785-793

Lesica P, Miles S (2001) Tamarisk growth at the northern margin of its naturalized range in Montana, USA. Wetlands 21:240-246

Linkosalo T, Lechowicz MJ (2006) Twilight far-red treatment advances leaf bud burst of silver birch (Betula pendula). Tree Physiol 26:1249-1256

Luquez V, Hall D, Albrectsen BR, Karlsson J, Ingvarsson P, Jansson S (2008) Natural phenological variation in aspen (Populus tremula): the SwAsp collection. Tree Genet Genomes 4:279-292

Maron JL, Vilà M, Bommarco R, Elmendorf S, Beardsley P (2004) Rapid evolution of an invasive plant. Ecol Monogr 74:261-280

McMillan C (1957) Nature of the plant community. IV. Phenological variation within five woodland communities under controlled temperatures. Am J Bot 44:154-163

Morin X, Augspurger C, Chuine I (2007) Process-based modeling of species' distributions: what limits temperate tree species' range boundaries? Ecology 88:2280-2291

Nienstaedt H (1974) Genetic variation in some phenological characteristics of forest trees. In: Lieth $\mathrm{H}$ (ed) Phenology and seasonality modeling. Springer-Verlag, New York, pp 389-400

Pauley SS, Perry TO (1954) Ecotypic variation of the photoperiodic response in Populus. J Arnold Arboretum 35:167-188

Perry TO (1971) Dormancy of trees in winter. Science 171:29-36

R Development Core Team (2003) R: a language and environment for statistical computing. http://www.R-project.org. Accessed 02 June 2008

Rehfeldt GE, Ying CC, Spittlehouse DL, Hamilton DA Jr (1999) Genetic responses to climate in Pinus contorta: niche breadth, climate change, and reforestation. Ecol Monogr 69:375-407

Repo T, Zhang G, Ryyppö A, Rikala R, Vuorinen M (2000) The relation between growth cessation and frost hardening in Scots pines of different origins. Trees 14:456-464

Robinson TW (1965) Introduction, spread and aerial extent of saltcedar (Tamarix) in the western states. US Geological Survey Professional Paper 491-A. US Government Printing Office, Washington, DC

Sakai A (1970) Freezing resistance in willows from different climates. Ecology 51:485-491
Sakai A, Larcher W (1987) Frost survival of plants: responses and adaptation to freezing stress. Springer-Verlag, New York

Sakai A, Weiser CJ (1973) Freezing resistance of trees in North America with reference to tree regions. Ecology 54:118-126

Saxe H, Cannell MGR, Johnsen Ø, Ryan MG, Vourlitis G (2001) Tree and forest functioning in response to global warming. New Phytologist 149:369-400

Schaber J, Badeck FW (2003) Physiology-based phenology models for forest tree species in Germany. Int J Biometeorol 47:193-201

Sexton JP, McKay JK, Sala A (2002) Plasticity and genetic diversity may allow saltcedar to invade cold climates in North America. Ecol Appl 12:1652-1660

Shafroth PB, Cleverly JR, Dudley TL, Stuart J, Taylor JP, van Riper C, Weeks EP (2005) Control of Tamarix in the western U.S.: implications for water salvage, wildlife use, and riparian restoration. Environ Manag 35:231-246

Sultan SE (2000) Phenotypic plasticity for plant development, function and life history. Trends Plant Sci 5:537-542

Thornton PE, Running SW, White MA (1997) Generating surfaces of daily meteorology variables over large regions of complex terrain. J Hydrol 190:214-251

Tsarouhas V, Kenney WA, Zsuffa L (2001) Variation in freezing resistance during different phenological stages in some Populus and Salix clones: Implications for clonal selection. Silvae Genet 50:54-63

Turesson G (1930) The selective effect of climate upon the plant species. Hereditas 14:99-152

USDA, NRCS (2009) The PLANTS Database. National Plant Data Center, Baton Rouge. http://plants.usda.gov. Accessed 01 June 2009

Van Haverbeke DF (1990) Plains cottonwood. In: Burns RM, Honkala BH (technical coordinators), Silvics of North America: volume 2, Hardwoods. Agriculture Handbook 654, USDA Forest Service, Washington, DC, pp 536-543

Venables WN, Ripley BD (1999) Modern applied statistics with SPlus, 3rd edn. Springer-Verlag, New York

Viherä-Aarnio A, Häkkinen R, Partanen J, Luomajoki A, Koski V (2005) Effects of seed origin and sowing time on timing of height growth cessation of Betula pendula seedlings. Tree Physiol 25:101-108

Vitasse Y, Delzon S, Dufrêne E, Pontailler JY, Louvet JM, Kremer A, Michalet R (2009) Leaf phenology sensitivity to temperature in European trees: do within-species populations exhibit similar responses? Agric For Meteorol 149:735-744

Vitasse Y, Bresson CC, Kremer A, Michalet R, Delzon S (2010) Quantifying phenological plasticity to temperature in two temperate tree species. Funct Ecol. doi:10.1111/j.1365-2435.2010.01748.x

Wareing PF (1956) Photoperiodism in woody plants. Annual Rev Plant Physiol 7:191-214

Weber E, Schmid B (1998) Latitudinal population differentiation in two species of Solidago (Asteraceae) introduced into Europe. Am J Bot 85:1110-1121

Ying CC, Bagley WT (1976) Genetic variation of eastern cottonwood in an eastern Nebraska provenance study. Silvae Genet 25:67-73

Zhang X, Friedl MA, Schaaf CB, Strahler AH (2004) Climate controls on vegetation phenological patterns in northern mid- and high latitudes inferred from MODIS data. Glob Chang Biol 10:1133-1145 
Online Resource 1 for "Genetic and environmental influences on leaf phenology and cold hardiness of native and introduced riparian trees" by JM Friedman, JE Roelle and BS Cade, in International Journal of Biometeorology. Corresponding author: Jonathan M Friedman, US Geological Survey, friedmanj@usgs.gov. A table showing collection locations and number of individuals planted on 16 August 2005, for plains cottonwood (Populus deltoides subsp. monilifera) and saltcedar (Tamarix ramosissima, Tamarix chinensis, and hybrids) grown in the common garden in Fort Collins, Colorado (latitude $40.58^{\circ} \mathrm{N}$ ).

Latitude Longitude Elevation Number planted

Site name

$\left({ }^{\circ} \mathrm{N}\right) \quad\left({ }^{\circ} \mathrm{W}\right)$

(m) Saltcedar Cottonwood

Fort Peck Reservoir, Hell Creek Arm, Montana $47.60 \quad 106.90 \quad 683 \quad 22 \quad 25$

$\begin{array}{llllll}\text { Musselshell River near Roundup, Montana } & 46.45 & 108.53 & 962 & 25 & 21\end{array}$

$\begin{array}{llllll}\text { Powder River near Broadus, Montana } & 45.43 & 105.41 & 927 & 24 & 25\end{array}$

$\begin{array}{llllll}\text { Keyhole Reservoir, Wyoming } & 44.37 & 104.79 & 1,254 & 25 & 32\end{array}$

$\begin{array}{llllll}\text { Boysen Reservoir, Wyoming } & 43.22 & 108.18 & 1,379 & 25 & 25\end{array}$

$\begin{array}{llllll}\text { Lake McConaughy, Nebraska } & 41.29 & 101.93 & 988 & 25 & 25\end{array}$

$\begin{array}{lllll}\text { Cache la Poudre River, Fort Collins, Colorado } & 40.56 & 105.01 & 1,504 & 32\end{array}$

$\begin{array}{llllll}\text { Bonny Reservoir, Colorado } & 39.62 & 102.19 & 1,120 & 22 & 24\end{array}$

$\begin{array}{llllll}\text { Arkansas River, Colorado } & 38.09 & 102.29 & 1,053 & 25 & 25\end{array}$

$\begin{array}{llllll}\text { Cimarron River, Oklahoma } & 37.12 & 101.89 & 1,036 & 25 & 25\end{array}$

$\begin{array}{llllll}\text { Lake Meredith, Mullinaw Creek, Texas } & 35.53 & 101.77 & 896 & 25 & 24\end{array}$

$\begin{array}{lllll}\text { Buffalo Lake National Wildlife Refuge, Texas } & 34.90 & 102.12 & 1,105 & 22\end{array}$

$\begin{array}{llllll}\text { Lake Alan Henry, Texas } & 33.06 & 101.04 & 649 & 22 & 12\end{array}$

$\begin{array}{llllll}\text { Colorado River west of Silver, Texas } & 32.02 & 100.74 & 581 & 24 & 0\end{array}$

Tornillo Creek, Big Bend National Park, Texas $29.18 \quad 103.01 \quad 568 \quad 25 \quad 0$ 
Online Resource 2 for "Genetic and environmental influences on leaf phenology and cold hardiness of native and introduced riparian trees" by JM Friedman, JE Roelle and BS Cade, in International Journal of Biometeorology. Corresponding author: Jonathan M Friedman, US Geological Survey, friedmanj@usgs.gov. A figure showing variation in climate among collection locations.

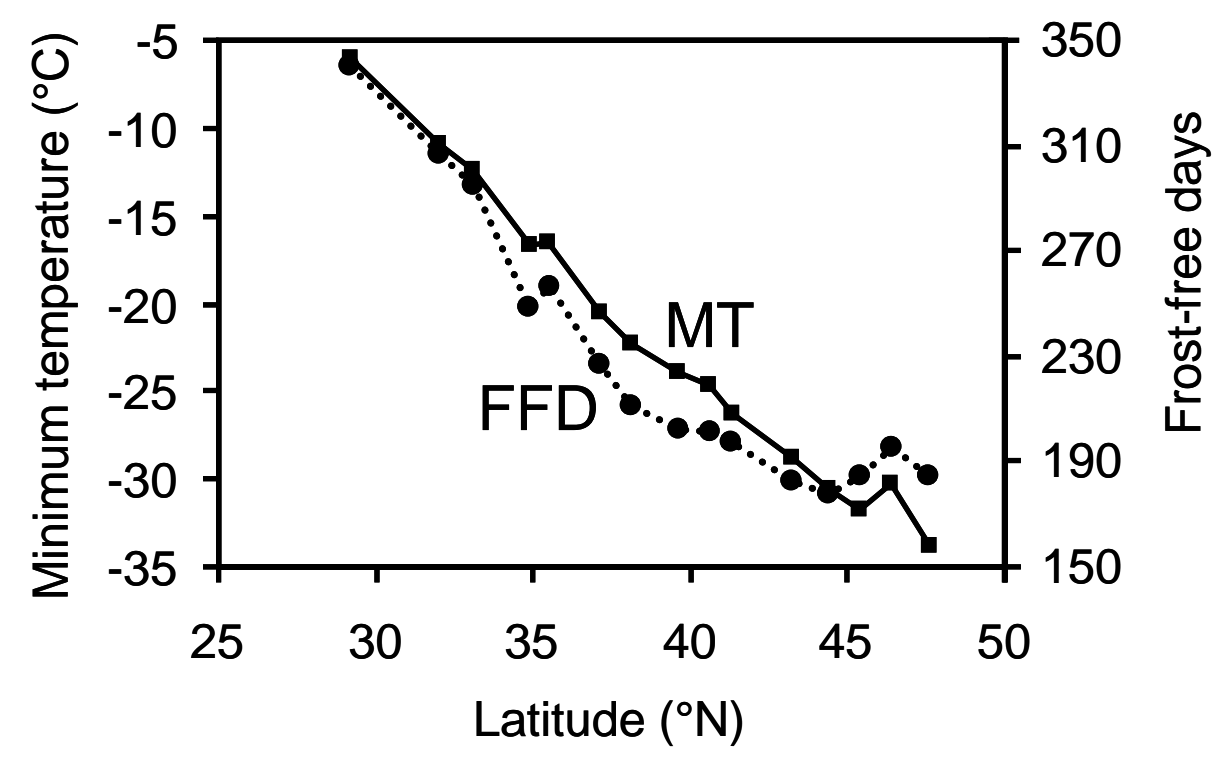

Latitudinal variation in mean annual extreme minimum temperature (MT, solid line) and mean annual number of frost-free days (FFD, dotted line) in the central United States. Locations of data points are described in Online Resource 1 and climate data are calculated from the DAYMET interpolated daily low temperature series for the period 1980-2003 gridded at 1-km resolution (Thornton et al. 1997, http://www.daymet.org).

The latitudinal gradient sampled in this study corresponds to a climatic gradient in that northern sites are colder and have a shorter growing season. Mean annual extreme minimum temperature shows a linear decrease with increasing latitude $\left(r^{2}\right.$ of linear regression $\left.=0.98\right)$. The mean annual number of frost-free days also decreases with increasing latitude $\left(\mathrm{r}^{2}\right.$ of linear regression $\left.=0.85\right)$, but the slope becomes less steep with increasing latitude. The underlying reason for this trend is that elevation increases with 
increasing latitude from 29.2 to $40.6^{\circ} \mathrm{N}$, but decreases with increasing latitude north of latitude $40.6^{\circ} \mathrm{N}$

(Online Resource 1). Since temperatures decrease with increasing elevation, the elevation effect strengthens the climatic gradient from 29.2 to $40.6^{\circ} \mathrm{N}$, but weakens it from 40.6 to $47.6^{\circ} \mathrm{N}$. 
Online Resource 3 for "Genetic and environmental influences on leaf phenology and cold hardiness of native and introduced riparian trees" by JM Friedman, JE Roelle and BS Cade, in International Journal of Biometeorology.

Corresponding author: Jonathan M Friedman, US Geological Survey, friedmanj@ usgs.gov. Mean values of phenological characters by latitude of origin.

Spring phenology

\begin{tabular}{lrrr} 
& & \multicolumn{2}{c}{ Leaf flush } \\
\cline { 3 - 4 } $\begin{array}{l}\text { Species } \\
\text { or effect }\end{array}$ & $\begin{array}{c}\text { Latitude } \\
\text { of origin }\end{array}$ & 2007 & 2008 \\
\hline Cottonwood & & & \\
& 33.1 & 1-May & 16-May \\
34.9 & 30-Apr & 14-May \\
35.5 & 2-May & 17-May \\
37.1 & 29-Apr & 15-May \\
38.1 & 29-Apr & 11-May \\
39.6 & 30-Apr & 13-May \\
40.6 & 2-May & 14-May \\
41.3 & 1-May & 14-May \\
43.2 & 30-Apr & 13-May \\
44.4 & 30-Apr & 13-May \\
45.4 & 3-May & 16-May \\
46.4 & 3-May & 13-May \\
47.6 & 30-Apr & 14-May \\
Latitude effect & 0 & 0
\end{tabular}

Saltcedar

$\begin{array}{rrrrr}29.2 & \text { 30-Apr } & \text { 6-May } & \text { 22-Jul } & \text { 16-Jun } \\ 32 & \text { 16-Apr } & \text { 21-Apr } & \text { 30-May } & \text { 23-May } \\ 33.1 & \text { 12-Apr } & \text { 21-Apr } & \text { 19-Jun } & \text { 25-May } \\ 34.9 & \text { 6-Apr } & \text { 23-Apr } & \text { 1-Jun } & \text { 24-May } \\ 35.5 & \text { 11-Apr } & \text { 23-Apr } & \text { 8-Jun } & \text { 24-May } \\ 37.1 & \text { 8-Apr } & \text { 23-Apr } & \text { 5-Jun } & \text { 22-May } \\ 38.1 & \text { 11-Apr } & \text { 23-Apr } & \text { 2-Jun } & \text { 22-May } \\ 39.6 & \text { 12-Apr } & \text { 23-Apr } & \text { 30-May } & \text { 23-May } \\ 40.6 & \text { 8-Apr } & \text { 25-Apr } & \text { 23-May } & \text { 24-May } \\ 41.3 & \text { 8-Apr } & \text { 22-Apr } & \text { 21-May } & \text { 22-May } \\ 43.2 & \text { 4-Apr } & \text { 24-Apr } & \text { 22-May } & \text { 23-May } \\ 44.4 & \text { 7-Apr } & \text { 25-Apr } & \text { 23-May } & \text { 24-May } \\ 45.4 & \text { 11-Apr } & \text { 25-Apr } & \text { 27-May } & \text { 26-May } \\ 46.4 & \text { 12-Apr } & \text { 24-Apr } & \text { 31-May } & \text { 25-May } \\ 47.6 & \text { 6-Apr } & \text { 27-Apr } & \text { 25-May } & \text { 27-May } \\ \text { effect } & 0 & -4 & 7 & \text {-3 }\end{array}$

Fall phenology

\begin{tabular}{|c|c|c|c|}
\hline \multicolumn{3}{|c|}{ Bud formation } & \multirow{2}{*}{$\begin{array}{l}\begin{array}{l}\text { Leaf } \\
\text { senescence }\end{array} \\
2007\end{array}$} \\
\hline 2006 & 2007 & 2008 & \\
\hline 13-Sep & 2-Sep & 12-Aug & 6-Nov \\
\hline 18-Sep & 1-Sep & 31-Jul & 4-Nov \\
\hline 19-Sep & 27-Aug & 28-Jul & 2-Nov \\
\hline 13-Sep & 30-Aug & 29-Jul & 2-Nov \\
\hline 5-Sep & 19-Aug & 25-Jul & 29-Oct \\
\hline 2-Sep & 19-Aug & 23-Jul & 19-Oct \\
\hline 31-Aug & 8-Aug & 17-Jul & 24-Oct \\
\hline 30-Aug & 14-Aug & 21-Jul & 20-Oct \\
\hline 30-Aug & 27-Jul & 12-Jul & 14-Oct \\
\hline 29-Aug & 28-Jul & 9-Jul & 16-Oct \\
\hline 29-Aug & 31-Jul & 8-Jul & 13-Oct \\
\hline 29-Aug & 26-Jul & 8-Jul & 17-Oct \\
\hline 29-Aug & 26-Jul & 8-Jul & 14-Oct \\
\hline 20 & 37 & 23 & 21 \\
\hline
\end{tabular}

\section{5-Nov}

27-Oct

25-Oct

23-Oct

26-Oct

18-Oct

19-Oct

18-Oct

18-Oct

18-Oct

16-Oct

15-Oct

15-Oct

$19-$-Oct

$13-$ Oct 10

4.7

Species effect

$21.9 \quad 20.4$

For the purposes of this table the latitude effect for a given species and phenological character is the difference in days between the mean values for latitudes $34.9^{\circ} \mathrm{N}$ and $47.6^{\circ} \mathrm{N}$. We selected these two latitudes because they were the most northern and southern latitudes with abundant 
individuals of both species (Online Resource 1). The species effect for a given character is the difference in days between the values for cottonwood and saltcedar averaged across all common latitudes of origin. 
Online Resource 4 for "Genetic and environmental influences on leaf phenology and cold hardiness of native and introduced riparian trees" by JM Friedman, JE Roelle and BS Cade, in International Journal of Biometeorology. Corresponding author: Jonathan M Friedman, US Geological Survey, friedmanj@ usgs.gov. A figure showing overwinter survival in the first year (2005-2006) for plains cottonwood (Populus deltoides subsp. monilifera) and saltcedar (Tamarix ramosissima, Tamarix chinensis, and hybrids) in the common garden (latitude $40.58^{\circ} \mathrm{N}$ ) as a function of latitude of origin. Survival is the proportion of plants alive on 5 September 2005 that were still alive on 30 May 2006. Winter damage to plants in the common garden was related to latitude in saltcedar but not in cottonwood. In the first winter after planting, 2005-2006, overwinter survival of saltcedar was low for the three southernmost latitudes $(29.2,32.0$, and $33.1^{\circ} \mathrm{N}$ ), but there was no relation between over-winter survival of cottonwood and latitude of origin. During the winters of 2006-2007 and 2007-2008 over-winter survival of whole plants was $>99 \%$ and unrelated to latitude for both species (data not shown).

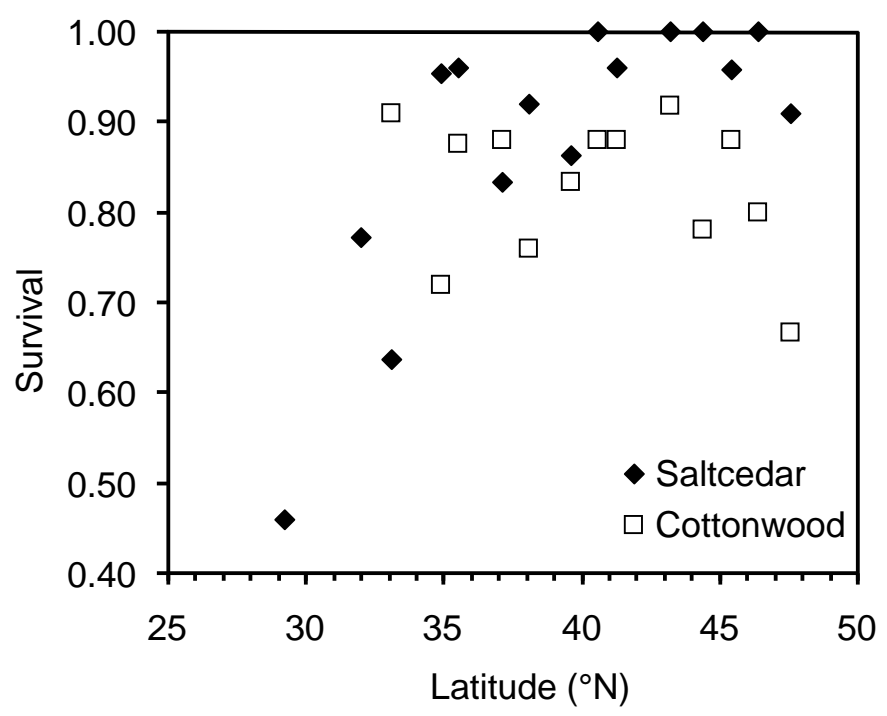


In addition to the observations of whole plant mortality reported in the figure above, we made observations of stem mortality. Saltcedar from the southernmost latitude $\left(29.2^{\circ} \mathrm{N}\right)$ commonly died back to the ground in winter and then resprouted (13 of 17 plants in 2006-2007 and 7 of 16 of plants in 2007-2008). Such dieback was rare for other latitudes of origin in both species, which is consistent with the fact that measured stem killing temperatures for all latitudes tested were always below the daily minimum temperature on the day of sampling (Fig. 1). The decrease in winter damage to both species over the 3-year period is not related to a trend in temperatures. Extreme cold temperatures were similar for the three winters (Colorado Climate Center, unpublished data). Instead, the plants became hardier as they grew older and larger. Stem death in saltcedar from latitude $29.2^{\circ} \mathrm{N}$ occurred in mid-winter. In the winter of 2006-2007 we began observing dead stems from latitude $29.2^{\circ} \mathrm{N}$ on February 28 , and in the winter of $2007-$ 2008 we began observing dead stems on January 28. No comparable observations were made during the winter of 2005-2006. In both the 2006-2007 and 2007-2008 winters dead stems appeared after the day of the coldest minimum temperature of the winter $\left(-24.9^{\circ} \mathrm{C}\right.$ on 2 February 2007 and $-24.7^{\circ} \mathrm{C}$ on 22 January 2008). These minimum temperatures apparently caused mortality of saltcedar stems from latitude $29.2^{\circ} \mathrm{N}$ even though our measured mid-winter killing temperature for such stems was about $-30^{\circ} \mathrm{C}$ (Fig. 2), suggesting that the brief exposure to cold in our freezing trials may result in slight underestimation of the killing temperature. 